\title{
FERTILITY OF COWS AFTER DYSTOCIAS AND COMPLICATED PUERPERIUM WITH RESPECT TO BACTERIOLOGICAL AND MYCOLOGICAL FINDINGS IN THE GENITALIA
}

\author{
Z. VLČEK, E. KUDLÁČ, Eva NESŇALOVÁ and Alena LÁNÍKOVÁ \\ University of Veterinary Science, 61242 Brno
}

Received February 22, 1988

\begin{abstract}
Vlček Z., E. Kudláč, Eva Nesňalová and Alena Láníková: Fertility of Cows after Dystocias and Complicated Puerperium with Respect to Bacteriological and Mycological Findings in the Genitalia. Acta vet. Brno, 58, 1989: 245 - 260.

Seventy-three cows with the history of laboured calving and complicated puerperium were observed for persisting pathological conditions in the genitalia, the incidence of bacteria and micromycetes in the cervical mucus and for subsequent fertility. Clinical examination at 28 to 32 days after parturition revealed persisting pathological processes, mainly inflammations, in the genitalia of $75.34 \%$, incomplete involution of the uterus in $50.68 \%$, absence of the sexual cycle in $26.02 \%$ and the incipient syndrome of ovarian cysts in $17.80 \%$ of the cows. By 55 to 65 days post partum the incidence of pathological processes had substantially decreased, the most frequently processes then observed being inflammations (in $34.24 \%$ of the cows), particularly mucopurulent endometritis (in $17.80 \%$ of the cows).

Bacteriological and mycological examination detected, in keeping with the incidence of pathological processes, a number of pathogenic species. The most frequently identified bacteria and micromycetes were Actinomyces pyogenes, Staphylococcus aureus and beta-streptococci, and Aspergillus fumigatus, Aspergillus flavus, Aspergillus ochraceus and Aspergillus parasiticus, respectively. Compared with the means obtained in the respective herds, the cows yielding pathogenic and potentially pathogenic micromycetes showed a higher incidence of reproductive disorders, worse reproduction indices and a higher cullig rate, while cows yielding pathogenic and potentially pathogenic bacteria also showed a higher incidence of reproductive disorders and a higher culling rate but their reproduction indices, except insemination interval, were unaffected.
\end{abstract}

Cattle, parturition, puerperium, bacteria, micromycetes, reproduction

The importance of a non-complicated parturition and puerperium for further fertility and performance of the cow has long been recognized. Much attention has therefore been paid to the aetiology, therapy and prophylaxis of pathological con- 
ditions impairing involution of the genitalia and delaying the return of cows to the reproductive process or causing their premature culling. A number of studies are available concerning puerperal changes and processes underlying the return of the reproductive organs to a morphological and functional state permitting another pregnancy (Vlček 1969; Kudláč and Vlček 1970; Kudláč et al. 1970; Buchholz and Busch 1977; Garcia 1982; Garcia and Larson 1982), the effects of environmental and internal factors on the course of puerperium, and the possibilities to control the puerperium and stimulate its early completion (Kudláč 1982; Vlček 1982; Vlček and Svobodová 1985; Laktiš 1977; Leidl et al. 1983; Bostedt et al. 1980; a.o.).

Other experiments by the aforementioned and other investigators were conducted in cows with a pathological course of parturition (Gamčík et al. 1983; Bostedt et al. 1979; Bostedt 1984; Buchholz et al. 1979; Sobiraj et al. 1987; a.o.) in an attempt to assess the dynamics of demonstrable alterations in the individual parts of the genitalia, subsequent reproductive disorders, efficiency of treatment using various procedures and therapeutic drugs, rate of return of the cows to the reproductive process, culling rate, losses due to puerperal complications, a.o.

The present study was designed as a contribution to a better understanding of these aspects.

\section{Materials and Methods}

The experimental animals were 73 Bohemian Pied cows or their crosses with the Holstein-Friesian breed with the history of a pathological course of the latest calving or puerperium, either untreated or therapeutically treated, chosen by systematic search in herds with comparable management and feeding practices on several farms of an agricultural enterprise. They were subjected to clinical, bacteriological and mycological examination 28 to 32 and 55 to $65 \mathrm{~d}$ after calving. Clinical examination (assessment of the general health status and external, vaginal and rectal examination of the genitalia) was focussed on the determination of the involution degree, renewal of ovarian activity, oestrus onset, inflammatory processes and other pathological changes, the syndrome of ovarian cysts a.o.

Bacteriological and mycological examination was carried out with routine methods to detect pathogenic and potentially pathogenic bacteria and micromycetes in the cervical mucus and to evaluate their incidence with respect to clinical findings and subsequent fertility.

The animals were permanently observed and eventually evaluated on the basis of either pregnancy diagnosis or infertility diagnosis and culling. The evaluation covered basic reproduction indices (conception at first and further inseminations, insemination interval, service-period, insemination index, rate of return to the reproductive process and culling rate) with respect to gynecological, bacteriological and mycological findings under consideration of age and season (summer ration vs. winter ration).

\section{Results and Discussion}

The survey of pathological conditions diagnosed in the cows at parturition and during the puerperium is presented in Table 1 . It can be seen that the most frequent complications were puerperal endometritis and retained placenta found in $54.79 \%$ and $53.42 \%$ of the cows, respectively. Substantially less frequent complications were laboured parturition, prolapse of the uterus, metritis a.o. 
Table 1. Prevailing pathological conditions at parturition and post partum in the experimental group of cows

\begin{tabular}{|l|c|c|}
\hline $\begin{array}{c}\text { Character and incidence } \\
\text { (\%) of pathological } \\
\text { conditions }\end{array}$ & $\begin{array}{c}\text { \% affected } \\
\text { cows in } \\
\text { the sample }\end{array}$ & $\begin{array}{c}\text { \% affected cows } \\
\text { in the population } \\
\text { under study }\end{array}$ \\
\hline $\begin{array}{l}\text { Laboured of a large calf } \\
\text { or stillbirth }\end{array}$ & 9.58 & 0.94 \\
$\begin{array}{l}\text { Laboured birth or } \\
\text { abortion of twins }\end{array}$ & 9.58 & 0.94 \\
Premature calving & 6.84 & 0.67 \\
Late abortion & 4.10 & 0.40 \\
Prolapse of the uterus & 5.47 & 0.53 \\
Retained placenta & 53.42 & 5.24 \\
Puerperal endometritis & 54.79 & 5.37 \\
Metritis, perimetritis, & 4.10 & 0.40 \\
parametritis & & \\
\hline
\end{tabular}

n

Age $\bar{x}$

No. parturitions $\bar{x}$
73

5.51

3.75
744

not examined not examined

Table 2. Incidence and character of pathological changes in the genitalia diagnosed on external, vaginal and rectal examination of the cows 1 and 2 months post partum

\begin{tabular}{|c|c|c|c|c|}
\hline$\cdot$ & \multicolumn{2}{|c|}{$\begin{array}{l}\text { Examination } 1 \text { month } \\
\text { post partum }\end{array}$} & \multicolumn{2}{|c|}{$\begin{array}{l}\text { Examination } 2 \text { months } \\
\text { post partum }\end{array}$} \\
\hline & No. & $\%$ & No. & $\%$ \\
\hline $\begin{array}{l}\text { Cows in the experiment } \\
\text { Cows culled } \\
\text { No pathological findings } \\
\text { Cervicitis } \\
\text { First-degree endometritis } \\
\text { Second-degree endometritis } \\
\text { Third-degree endometritis } \\
\text { Endometritis + metritis } \\
\text { Residues (adhesions a.o.) followig } \\
\text { metritis, perimetritis or parametritis } \\
\text { Total No. and \% cows with } \\
\text { inflammatory changes in the genitalia } \\
\text { Cows with the incipient and later } \\
\text { confirmed syndrome of ovarian cysts } \\
\text { Total No. and \% cows with } \\
\text { pathological findings in the genitalia }\end{array}$ & $\begin{array}{r}73 \\
18 \\
2 \\
1 \\
26 \\
4 \\
3 \\
6 \\
42 \\
13\end{array}$ & $\begin{array}{r}100 \\
24.65 \\
2.73 \\
1.36 \\
35.61 \\
5.47 \\
4.10 \\
8.21 \\
57.53 \\
17.80\end{array}$ & $\begin{array}{r}71 \\
2 \\
33 \\
2 \\
13 \\
2 \\
2 \\
6 \\
25 \\
13\end{array}$ & $\begin{array}{r}97.26 \\
2.73 \\
45.20 \\
2.73 \\
\overline{17.80} \\
2.73 \\
2.73 \\
8.21 \\
34.24 \\
17.80\end{array}$ \\
\hline
\end{tabular}


Table 3. Involution of the uterus and ovarian activity in cows of the experimental group on examination 1 month post partum

\begin{tabular}{|c|c|c|c|c|c|c|}
\hline \multirow{2}{*}{$\begin{array}{c}\text { No. } \\
\text { cows }\end{array}$} & $\begin{array}{c}\text { \% } \\
\text { cows }\end{array}$ & completed & protracted & Uterine involution & & \multicolumn{3}{|c|}{ Ovarian activity } \\
\cline { 3 - 6 } & & & & & $\begin{array}{c}\text { incipient } \\
\text { syndrome } \\
\text { of ovarian } \\
\text { cysts }\end{array}$ & $\begin{array}{c}\text { not } \\
\text { restored }\end{array}$ \\
\hline 73 & 100 & 49.31 & 50.68 & 56.16 & 17.80 & 26.02 \\
\hline
\end{tabular}

Table 4. Bacterial contamination of the cervical mucus 1 and 2 months post partum in cows with the complicated course of parturition or puerperium

\begin{tabular}{|l|c|c|c|c|c|}
\hline & \multicolumn{5}{|c|}{ Degree of bacterial contamination (No. /\%) } \\
\cline { 2 - 6 } & S & I & II & III & $\begin{array}{c}\text { Total } \\
\text { positive }\end{array}$ \\
\hline $\begin{array}{l}\text { One month } \\
\text { after parturition }\end{array}$ & 36 & 19 & 11 & 7 & 37 \\
& 49.31 & 26.02 & 15.06 & 9.58 & 50.68 \\
$\begin{array}{l}\text { Two months } \\
\text { after parturition }\end{array}$ & 42 & 12 & 10 & 2 & 24 \\
\hline
\end{tabular}

$\mathbf{S}=$ bacteriologically negative samples

$I=$ solitary colonies (up to 6 colonies)

II $=$ medium contamination (up to 20 colonies)

III $=$ more than 20 colonies

Table 2 shows the survey of residual pathological states detected in the genitalia one and two months after parturition. The reduced incidence of positive findings 2 months post partum as compared to those observed 1 month after calving indicates a tendency to healing and restoration to normal. Whereas the examination at 28 to $32 \mathrm{~d}$ after calving detected pathological changes in the genitalia in $75.34 \%$ of the cows, that conducted at 55 to $65 \mathrm{~d}$ post partum revealed persistent pathological changes in $52.05 \%$ of the animals. Two cows $(2.73 \%)$ had been culled by this time. This implies that $17(23.28 \%)$ cows were cured. The persisting pathological conditions were mainly inflammatory processes (found in $34.24 \%$ of the cows), particularly mucopurulent endometritis (in $17.80 \%$ of the cows). Thirteen animals $(17.80 \%$ ) showed the incipient syndrome of ovarian cysts which was then confirmed by further examinations.

Involution of the uterus was clinically completed by about $30 \mathrm{~d}$ after calving in $36(49.31 \%)$ cows and protracted in $37(50.68 \%)$ animals. The ovarian cycle was restored in $41(56.16 \%)$, no signs of ovarian activity were observed in $19(26.02 \%)$ 
and the incipient syndrome of ovarian cysts was found in $13(17.80 \%)$ cows (Table 3 ). From these findings it appears that in most cows with a complicated course or parturition and puerperium the involution of the uterus and, occasionally, also the renewal of the sexual cycle are delayed, in consequence of which the insemination interval and the service-period are prolonged.

The results of bacteriological examination confirmed in keeping with our previous findings and those reported by other investigators (De Bois 1961; Lloyd et al. 1968; Vlček 1969, 1983; Vlček and Svobodová 1985) a substantial decrease in the content of both pathogenic and potentially pathogenic bacterial species in the cervical mucus during the period under study. In cows with the renewed sexual cycle only very low bacterial counts were found. It can be seen in Table 4 that although the bacteriological examination of the cervical mucous samples colleced 28 to $32 \mathrm{~d}$ after calving yielded positive results in $37(50.68 \%)$ cows, large bacterial counts were found only in $7(9.58 \%)$ animals. In most cows the isolation attempts yielded only solitary bacterial colonies (in 19 cows, i.e. in $26.02 \%$ of the animals) or negative results (in 36 cows, i.e. in $49.31 \%$ of the animals).

On examination at 55 to $66 \mathrm{~d}$ post partum positive findings were even less numerous, being found in $24(36.36 \%)$ cows. Major bacterial contamination of the cervical

Table 5. Survey and involvement of pathogenic, potentially pathogenic and saprophytic bacteria isolated from the cervical mucus of cows with the complicated course of parturition or puerperium 1 and 2 months post partum

\begin{tabular}{|c|c|c|c|c|c|c|}
\hline \multirow{2}{*}{ Species } & \multicolumn{2}{|c|}{$\begin{array}{l}1 \text { month } \\
\text { post partum }\end{array}$} & \multicolumn{2}{|c|}{$\begin{array}{l}2 \text { months } \\
\text { post partum }\end{array}$} & \multicolumn{2}{|c|}{$\begin{array}{c}\text { Total } \\
\text { incidence }\end{array}$} \\
\hline & No. & $\%$ & No. & $\%$ & No. & $\%$ \\
\hline Actinomyces pyogenes $(+++)$ & 6 & 8.21 & 5 & 7.57 & 11 & 7.91 \\
\hline Staphylococcus aureus $(+++)$ & 2 & 2.73 & 二 & - & 2 & 1.43 \\
\hline Staphylococcus epidermidis $(++)$ & 1 & 1.36 & - & - & 1 & 0.71 \\
\hline Escherichia coli $(++)$ & 6 & 8.21 & 1 & 1.51 & 7 & 5.03 \\
\hline Pseudomonas aeruginosa $(++)$ & 1 & 1.36 & 3 & 4.54 & 4 & 2.87 \\
\hline Proteus vulgaris $(+)$ & - & - & 1 & 1.51 & 1 & 0.71 \\
\hline Bacillus cereus $\left(t^{-}\right)$ & 2 & 2.73 & 1 & 1.51 & 3 & 2.15 \\
\hline Bacillus subtilis & 1 & 1.36 & - & - & 1 & 0.71 \\
\hline Bacillus sp. & 12 & 16.43 & 8 & 12.12 & 20 & 14.38 \\
\hline Alpha streptococci & 8 & 10.95 & 4 & 6.06 & 12 & 8.63 \\
\hline Beta streptococci $(++)$ & 2 & 2.73 & i & 1.51 & 3 & 2.15 \\
\hline Gamma streptococci & 1 & 1.36 & 1 & 1.51 & 2 & 1.43 \\
\hline Micrococcus sp. & 3 & 4.10 & 3 & 4.54 & 6 & 4.31 \\
\hline $\begin{array}{l}\text { Samples yielding pathogenic } \\
\text { bacterial species }(+++)\end{array}$ & 8 & 10.95 & 5 & 7.57 & 13 & 9.35 \\
\hline Samples yielding potentially & & & & & & \\
\hline $\begin{array}{l}\text { pathogenic bacterial species } \\
(++,+)\end{array}$ & 9 & 12.32 & 5 & 7.57 & 14 & 10.07 \\
\hline $\begin{array}{l}\text { Samples yielding saprophytic } \\
\text { bacterial species }(-)\end{array}$ & 20 & 27.39 & 14 & 21.21 & 34 & 24.46 \\
\hline $\begin{array}{l}\text { Total No. and \% bacteriologically } \\
\text { positive samples }\end{array}$ & 37 & 50.68 & 24 & 36.36 & 61 & 43.88 \\
\hline
\end{tabular}

+++ pathogenic species

,+++ potentially pathogenic species 


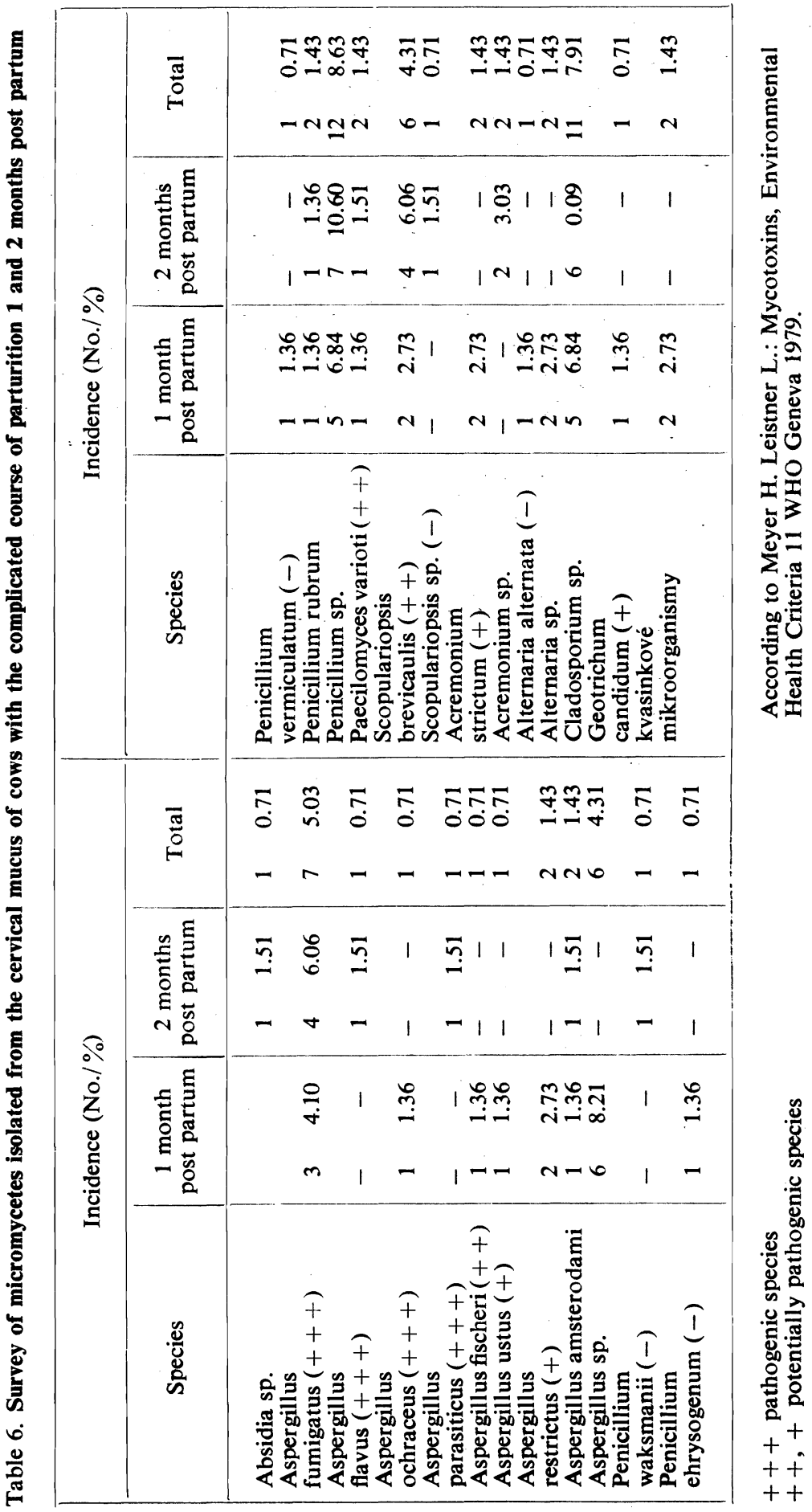


mucus was found in only $2(3.03 \%)$ cows, negative findings were recorded in 42 $(63.63 \%)$ cows and solitary colonies were found in $12(18.18 \%)$ cows. The number of findings showing medium contamination was approximately the same as before.

The survey of the isolated pathogenic and potentially pathogenic bacterial species is presented in Table 5. Of the species that may either produce pathological changes in the genitalia or be involved in their development, our isolation attempts yielded mainly Actinomyces pyogenes ("Corynebacterium pyogenes«) and Staphylococcus aureus which are involved particularly in the aetiology of suppurative processes. Potentially pathogenic bacteria isolated by us included Staphylococcus epidermidis, Escherichia coli, Pseudomonas aeruginosa and beta-streptococci.

Table 5 also shows the proportions of cows yielding pathogenic, potentially pathogenic and saprophytic bacteria 1 and 2 months after parturition. The finding of fewer pathogenic and potentially pathogenic species in the samples collected 55 to $65 \mathrm{~d}$ post partum is in keeping with the trend to amelioration of the health status, renewal of the sexual cycle and with the reduced total bacterial content of the genitalia.

Similar results were obtained upon mycological examination which yielded a relatively broad spectrum of micromycetes in the cervical mucus of cows with a complicated course of parturition and peurperium. Their survey, together with the incidence of the individual pathogenic, potentially pathogenic and saprophytic species is shown in Table 6. The pathogenic species were represented mainly by Aspergillus spp. (Aspergillus fumigatus, Aspergillus flavus, Aspergillus ochraceus, Aspergillus parasiticus) and the potentially pathogenic species, by Aspergillus fischeri, Aspergillus ustus, Aspergillus restrictus, Penicillium rubrum, Paecilomyces variotii, Scopulariopsis brevicaulis, Acremonium strictum and Geotrichum candidum (according to Mayer and Leistner: Mycotoxins, Environmental Health Criteria. 11. WHO Geneva 1979).

The incidence of pathogenic, potentially pathogenic and saprophytic micromycetes in the cervical mucus of cows with a complicated course of parturition and puerperium at 1 and 2 months post partum is shown in Table 7. Comparison with the results of bacteriological examination shows that the total incidence of micromycetes also decreased, but the proportion of persisting pathogenic and potentially pathogenic species remained higher.

The subsequent fertility of cows with the findings of pathogenic and potentially pathogenic bacteria and micromycetes is shown in Table 8. The proportion of cows that failed to conceive and were culled was $6.5 \%$ higher among those yielding pathogenic and potentially pathogenic bacteria than in the animals yielding saprophytic bacteria or negative findings $(44.00 \%$ vs. $37.50 \%)$. Similarly, in cows yielding pathogenic and potentially pathogenic micromycetes the proportion of those that failed to conceive and were culled was $8.2 \%$ higher than in the animals yielding saprophytic species or negative findings $(45.45 \%$ vs. $37.25 \%)$. Evaluation of the insemination interval, service-period and insemination index in cows that yielded pathogenic and potentially pathogenic micromycetes and conceived showed a substantial increase of all these values and delayed conception. That micromycetes may exert negative effects on reproduction in cattle was also pointed out by $R o b$ and Toman (1970), Feješ (1972) and Krpatová (1974). Our results obtained along this line in cows yielding pathogenic and potentially pathogenic bacteria are, except a prolonged insemination interval, not convincing (Table 8). However, our results were necessarily affected by the fact, demonstrated by our previous and current research, that pathological processes and infections of the genitalia are more frequent in younger cows which, on the other hand, respond better to therapy and show 


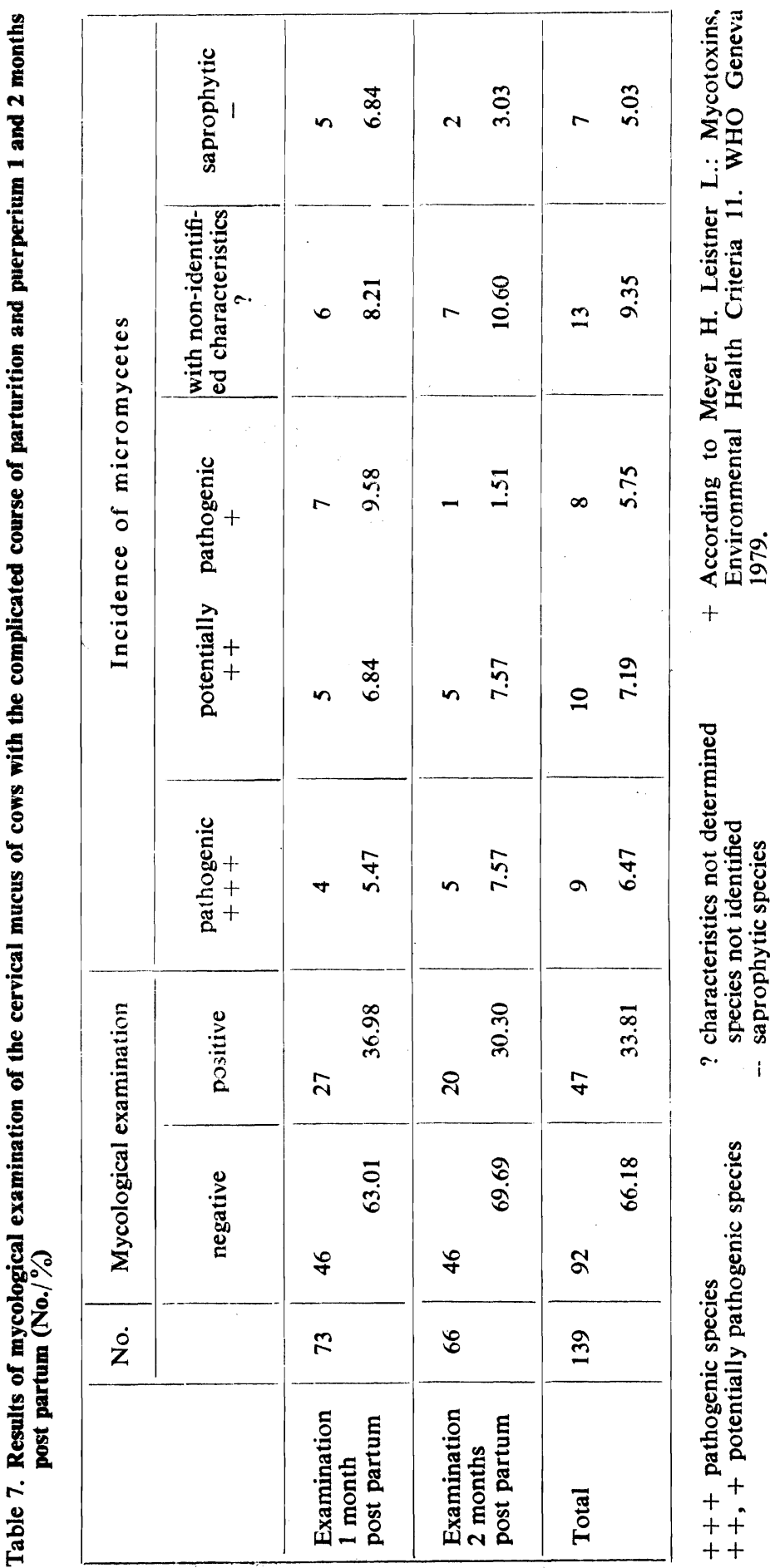


Table 8. Reproduction indices and culling of cows with positive and negative bacteriological and mycological findings

\begin{tabular}{|c|c|c|c|c|c|c|c|}
\hline \multirow[b]{2}{*}{$\begin{array}{l}\text { Cows yielding } \\
\text { pathogenic bacteria }\end{array}$} & \multicolumn{2}{|c|}{$\begin{array}{r}\text { No. } \% \\
\text { culled }\end{array}$} & \multicolumn{2}{|c|}{$\begin{array}{l}\text { No. } \% \\
\text { conceived }\end{array}$} & \multirow{2}{*}{$\begin{array}{c}\begin{array}{c}\text { Insemina- } \\
\text { tion interval } \\
\text { (days) }\end{array} \\
73.00\end{array}$} & \multirow{2}{*}{$\begin{array}{c}\begin{array}{c}\text { Service- } \\
\text {-period } \\
\text { (days) }\end{array} \\
85.50\end{array}$} & \multirow{2}{*}{$\begin{array}{c}\begin{array}{c}\text { Insemination } \\
\text { index }\end{array} \\
125\end{array}$} \\
\hline & 5 & 38.46 & 8 & 61.53 & & & \\
\hline $\begin{array}{l}\text { Cows yielding potentially } \\
\text { pathogenic bacteria }\end{array}$ & 6 & 50.00 & 6 & 50.00 & 69.00 & 98.33 & 2.00 \\
\hline $\begin{array}{l}\text { Cows yielding pathogenic } \\
\text { and potentially pathogenic } \\
\text { bacteria. Total }\end{array}$ & 11 & 44.00 & 14 & 56.00 & 71.28 & 91.00 & 1.57 \\
\hline $\begin{array}{l}\text { Cows yielding } \\
\text { saprophytic bacteria and } \\
\text { negative findings }\end{array}$ & 18 & 37.50 & 30 & 62.50 & 67.96 & 99.70 & 1.83 \\
\hline $\begin{array}{l}\text { Cows yielding } \\
\text { pathogenic micromycetes }\end{array}$ & 3 & 33.33 & 6 & 66.66 & 75.83 & 121.66 & 2.33 \\
\hline $\begin{array}{l}\text { Cows yielding potentially } \\
\text { pathogenic micromycetes }\end{array}$ & 7 & 53.84 & 6 & 46.15 & 68.33 & 104.00 & 1.83 \\
\hline $\begin{array}{l}\text { Cows yielding pathogenic } \\
\text { and potentially pathogenic } \\
\text { micromycetes. Total }\end{array}$ & 10 & 45.45 & 12 & 54.54 & 72.08 & 112.83 & 2.08 \\
\hline $\begin{array}{l}\text { Cows yielding saprophytic } \\
\text { and nonidentified micro- } \\
\text { mycetes and negative } \\
\text { findings }\end{array}$ & 19 & 37.25 & 32 & 62.74 & 67.87 & 90.96 & 1.62 \\
\hline
\end{tabular}

Table 9. Incidence of pathogenic and potentially pathogenic bacteria and micromycetes in the cervical mucus of cows with the complicated course of parturition and puerperium with respect to age (No./ \%)

\begin{tabular}{|l|c|c|c|c|c|c|c|}
\hline & \multicolumn{3}{|c|}{ Incidence of bacteria } & \multicolumn{3}{c|}{ Incidence of micromycetes } \\
\cline { 2 - 8 } & No. & $\begin{array}{c}\text { pathogenic } \\
+++\end{array}$ & $\begin{array}{c}\text { potentially pathogenic } \\
++\end{array}$ & $\begin{array}{c}\text { pathogenic } \\
+++\end{array}$ & $\begin{array}{c}\text { potentially pathogenic } \\
++\end{array}$ \\
\hline $\begin{array}{l}\text { Cows with } \\
\text { calvings }\end{array}$ & 39 & 9 & 6 & 0 & 6 & 3 & 2 \\
\hline $\begin{array}{l}\text { Cows with } \\
\text { and more } \\
\text { calvings }\end{array}$ & 34 & 23.07 & 15.38 & & 15.38 & 7.69 & 5.12 \\
\hline
\end{tabular}




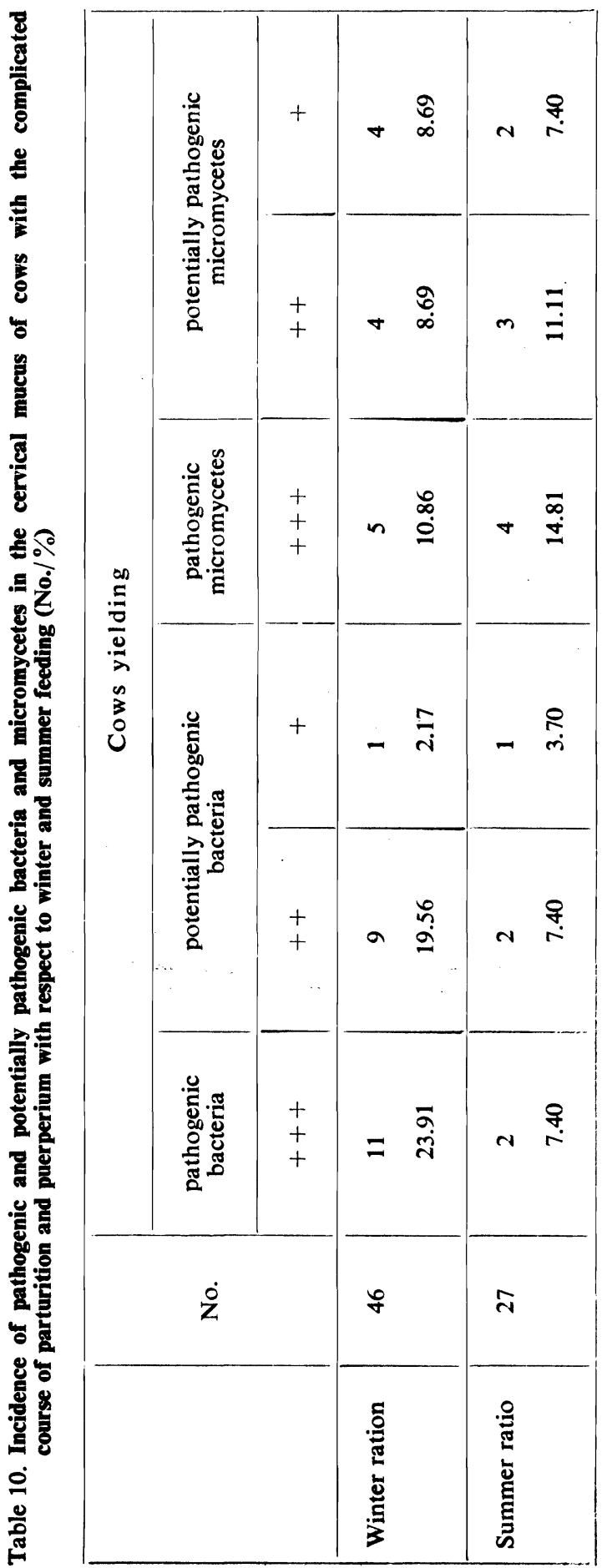




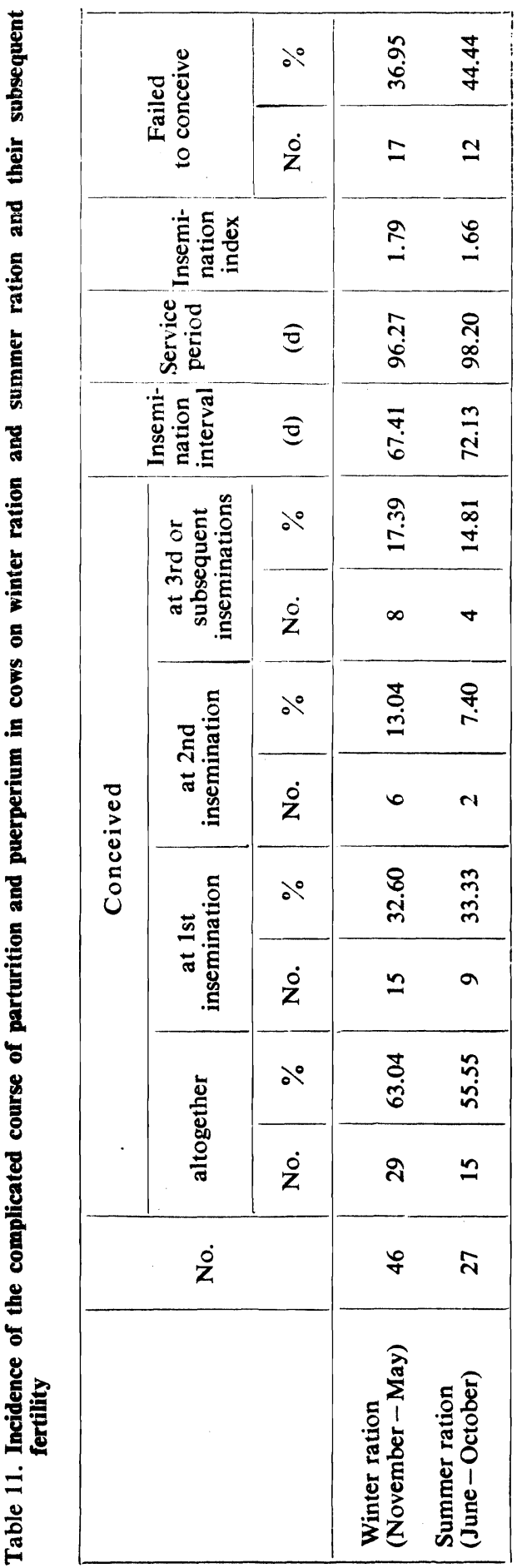




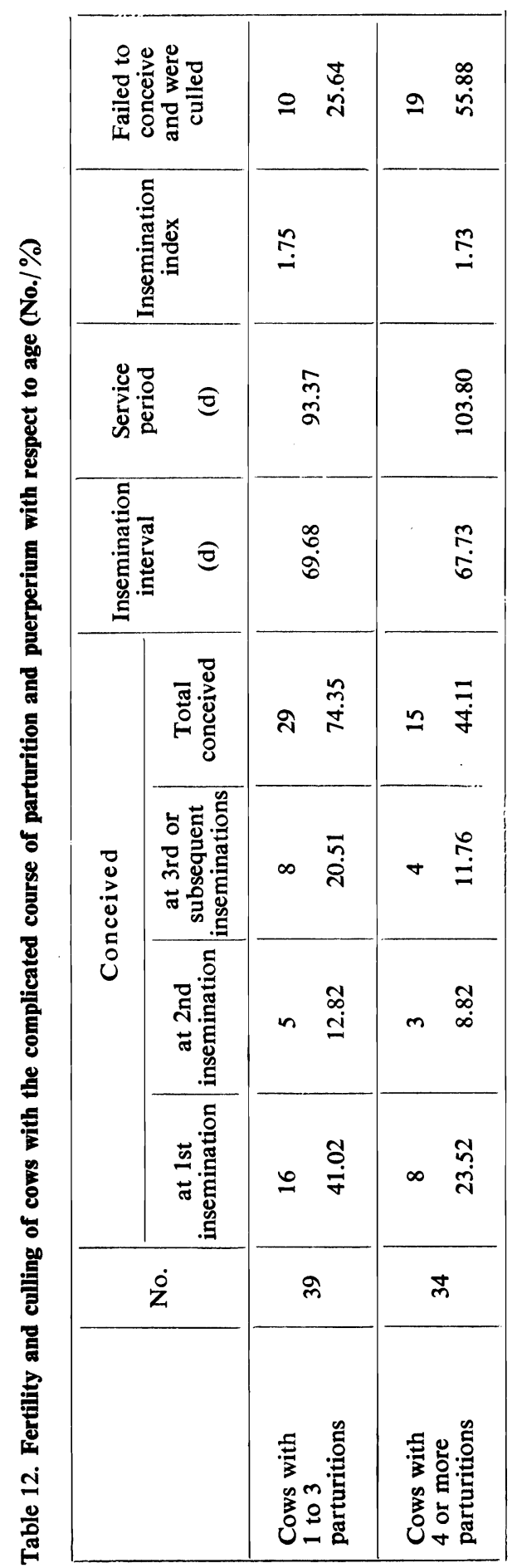




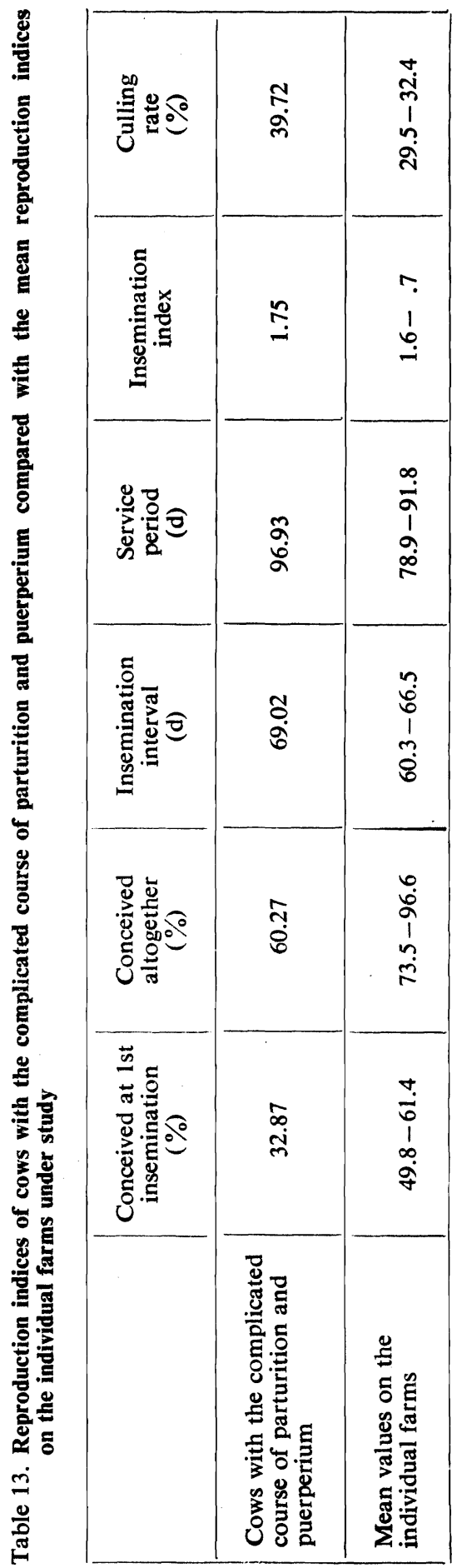


a better tendency to healing and renewed fertility than older animals (see Tables 9 and 12). Moreover, the results may have also been affected by the approach of the herdsman who is interested in systematic and intensive therapy particularly in younger cows with prospective higher performance and sometimes culls older animals without awaiting therapeutic results. The present findings confirm the fact that microbes do not exert a decisive effect on bovine health and reproduction but play a role in the interaction with other environmental effects and additional factors.

Comparison of the findings of bacteria and micromycetes in the cervical mucus of cows of various age categories (Table 9) showed a higher incidence of pathogens in younger cows with 1 to 3 calvings. However, the evidence from Table 12 comparing the reproduction indices and culling in cows of various ages also shows a better tendency to recovery and renewed fertilty in younger cows. Of I- to III-parous cows, $41.02 \%$ conceived at first insemination, altogether $74.35 \%$ conceived at first or subsequent inseminations and $25.64 \%$ failed to conceive and were culled. Of cows with the history of 4 or more calvings, only $23.52 \%$ conceived at first insemination, altogether $44.11 \%$ conceived at first or subsequent inseminations and $55.88 \%$ failed to conceive and were culled.

Table 10 shows the incidence of bacteria and micromycetes in the cervical mucus of cows with a complicated course of parturition and puerperium in relation to feeding (winter ration vs. summer ration). The findings of pathogenic and potentially pathogenic bacteria prevailed in winter and spring (in $45.64 \%$ vs. $18.50 \%$ cows) in keeping with the expected reduced resistance and higher occurrence of pathological conditions during these seasons. The incidence of pathogenic and potentially pathogenic micromycetes was higher in summer (in $33.33 \%$ vs. $28.24 \%$ cows). Environmental conditions favouring the multiplication of micromycetes and thereby also their penetration into the genitalia may occur both in winter and in summer. In winter the underlying causes are to be seen in insufficient ventilation of wet and warm barns, in inadequate storage of wet feed, etc. Similar conditions arise also in summer in consequence of rainy weather and mowburnt feed. Air-drying of mouldy feed in hot summer days then produces conditions favouring the spread of micromycetes in a dusty environment.

From Table 11 it can be seen that the incidence of cases with a complicated course of parturition and puerperium was higher in winter and spring, but the conception rate was lower and the culling rate was higher in summer. This fact may have also affected the evaluation and confirms our previous findings that in summer the saccharide-protein ratio of the ration is often less adequate and subclinical metabolic disorders exerting negative effects on fertility are more frequent.

Adverse effects of a complicated course of parturition and puerperium on subsequent fertility of the cows can be seen in Table 13. Of the affected cows, $29(39.72 \%)$ failed to conceive and were culled, a total of $44(60.27 \%)$ cows conceived, but the proportion of those conceiving at first insemination was only $32.87 \%$. The insemination interval was substantially prolonged and the service-period was longer than normal. A substantial impairment of all the reproduction indices becomes apparent on comparison with the mean values obtained on the individual farms of the agricultural enterprise under study. 
Plodnost krav po dystokiích a komplikovaném puerperiu se zřetelem $\mathbf{k}$ bakteriologickému a mykologickému nálezu v pohlavních orgánech

U 73 krav po těžkých porodech a komplikovaném puerperiu se zjištoval výskyt přetrvávajících chorobných stavủ na pohlavních orgánech, bakterií a mikromycetů $\mathrm{v}$ cervikálním hlenu a jejich vztah $\mathrm{k}$ dalši plodnosti. Za $28-32$ dnů po porodu ještě u 75,34 \% krav přetrvávaly na pohlavním ústrojí chorobné procesy - zejména záněty, u 50,68 \% nebyla klinicky ukončena involuce dělohy, u 26,02 \% se neobnovil pohlavní cyklus a u $17,80 \%$ se vytvářel syndrom ovariálních cyst. Za $55-65$ dnů po porodu se výskyt chorobných procesủ podstatně snižil. Přetrvávaly zejména záněty (u 34,24 \% krav), nejčastěji mukopurulentní endometritis (u 17,80\% krav).

Bakteriologickým a mykologickým vyšetřením byla $\mathrm{v}$ souladu $\mathrm{s}$ incidencí chorobných procesủ identifikována řada patogenních druhủ, $\mathrm{z}$ bakterií nejčastěji Actinomyces pyogenes, Staphylococcus aureus a beta-streptokoky, z mikromycetủ Aspergillus fumigatus, Aspergillus flavus, Aspergillus ochraceus a Aspergillus parasiticus. U krav s nálezem patogenních a příležitostně patogenních mikromycetủ se častěji vyskytovaly poruchy plodnosti, zhoršily se všechny reprodukční ukazatele a byla větší brakace. $U$ krav $s$ nálezem patogenních a príležitostně patogenních bakterií byl rovněž častějši výskyt poruch plodnosti a brakování, avšak až na interval se reprodukční ukazatele nezhoršily.

\section{Уровень репродукции коров после осложненного отела и осложненного послеродового периода с учетом бактериологического и микологического анализов в половых органах}

У 73 коров после тяжелого отела и осложненного послеродового периода выявляли наличие существующие заболеваний половых органов, бактерий и микромицетов в слизи шейки и устанавливали их отношение к дальнейшей плодовитости. Через 28-32 супок после родов еще у $75,34 \%$ коров встречались болезненные процеосы в половых органах, в особенности воспаления - 50,68 \% - клинически незавершенная инволюция матки - 26,02 \% коров не наблюдалось возобновление полового цикла и у $17,80 \%$ - образовался синдром кист яичника. Через 55-65 суток после отела наличие болезненных процессов существенно понизилось. Имели место в особенности воспаления (у $34,24 \%$ коров), чаще всего слизисто-пнойные воспаления эндометрия (у $17,80 \%$ коров).

Бактериологичеоким и микологическим иоследованиями с учетом болезненных процесоов определили ряд патогенных видов; из бактерий чаще всего Actinomyces pyogenes, Staphylococcus aureus и бета-стрепітококки, из микромицетов - Aspergillus fumigatus, Aspergillus flavus, Aspergillus ochraceus $и$ Aspergillus parasiticus. У коров с анализом патогенных и случайно патогенных микромицетов чаще всего встречались нарушения плодовитости, наступало ухудшение всех показателей репродукции с более существенной браковкой. У коров с патогенными и случайно патотенными бактериами наблюдались также частые нарушения плодовитости и выбраковка, однако, за исключением интервала, показатели репродукции не ухудшались. 


\section{References}

De BOIS, C. H. W.: Endometritis en vruchtbaarheid bij het rund. Thesis Utrecht 1961, 146 p.

BOSTEDT, H. - REISSINGER, H. - GÜNZLER, D.: Klinische Erfahrungen über dem Verlauf der Puerperalperiode bei Rindern von Beständen mit Fertilitätsproblemen. Berl. Münch. $t$. Wschr., 89, 1976: 24-28.

BOSTEDT, H. - SCHELZ, H. - GÜNZLER, D.: Klinische und bakteriologische Befunde im Genitaltrakt von Rindern nach gestörten Geburten in der ersten drei Wochen des Puerperiums. Zbl. Vet. Med., 26, 1979: 397-412.

BOSTEDT, H.: Uterine infections in the postpartum period. Proc. 10th Int. Congr. Anim. Reprod. Art. Insem. Illinois 1984: Vol. III, 25-33.

BOSTEDT, H.: Zur Fertilitätslage nach Puerperalerkrankungen des Rindes. Berl. Münch. t. Wschr., 92, 1979: 43-47.

BUCHHOLZ, G. W. - NATTERMANN, H. - STUMPE, K.: Untersuchungen in einem Rinderbestand über Beziehungen zwischen Puerperalverlauf und Bakterionflora des Uterus. Mh. Vet.-Med. 34, 1979: 372-376.

BUCHHOLZ, G. W. - BUSCH, W.: Untersuchungen über Beziehungen zwischen ovarieller Aktivität und Uterusinvolution bei Kühen post partum. Mh. Vet.-Med., 32, 1977: 95-97.

FEJES, J.: Výskyt húb vo vyšetrovaných čerstvých a hlboko mrazených ejakulátoch býkov $v$ období dvoch rokov a ich vplyv na plodnost. Veterinársky časopis Košice, 14, 1972: 187-190.

GAMČÍK, P. - ELEČKO, J. - KAČMÁRIK, J.: Methoden zur Beschleunigung des Puerperalverlaufs beim Rind. Mh. Vet.-Med., 38, 1983: 163-165.

GARCIA, M.: Reproductive functions during the post partum period in the cow (A review of the literature). Nord. Vet. Med., 34, 1982: 264-275.

GARCIA, M. - LARSON, K.: Clinical findings in post partum dairy cows. Nord. Vet. Med., 34, 1982: $255-263$.

KRPATOVÁ, J.: Mykologické nálezy v reprodukčních materiálech skotu. Veterinářství, 24, 1974: $347-348$.

KUDLÁČ, E.: Negativer Einfluss verschiedener Umweltfaktoren auf das Puerperium beim Rind und Möglichkeiten zur Steuerung dieser Periode. Deutsch. t. Wschr., 89, 1982: 329-333.

KUDLÁČ, E. - VINKLER, A. - VRTĚL, M. - VLČEK, Z.: Možnosti a naše poznatky při ovlivňování některých pohlavních funkcí skotu. Veterinářství, 32, 1982: 484-487.

KUDLÁČ, E. - VLČEK, Z.: Klinické změny na pohlavním ústrojí a obsah bakterií v děloze krav po normálním porodu. Vet. Med. Praha, 15, 1970: 11-19.

KUDLÁČ, E. - MINÁR̆, M. - VLČEK, Z.: Die Beziehung der ausgeschiedenen Geschlechtshormone zur Dynamik der bakteriellen Kontamination der Gebärmutter bei Kühen post partum. Fortpflanzung. Haust., 6, 1970: 331-339.

LAKTIŠ, J.: Sledovanie puerpéria kráv a možnosti jeho ovplyvnenia lokálnym ošetrením maternice. Thesis, VŠV Košice, 1979, 173 p.

LEIDL, W. - LÖVESTAD, A. M. - REISACH, R. - STURM, H.: Die Ovarfunktion beim Rind post partum sowic therapeutische Massnahmen bei deren Störung. Berl. Münch. $t$. Wschr., 96, 1983: $181-186$.

LLOYD, E. - MCMAHON, K. J. - GIER, H. T. - MARION, G. B.: Uterus of the Cow after Parturition. Bacterial Content. Am. J. Vet. Res., 29, 1968: 77-81.

ROB, O. - TOMAN, J.: Frekvence výskytu plisní ve spermatu a předkožkovém vaku plemenných býků. Vet. Med. Praha, 15, 1970: 703-708.

SOBIRAJ, A. - DRAEGER, K. G. - BOSTEDT, H.: Über den Einfluss von Nachgeburtsabgang auf den bakteriellen Keimgehalt des bovinen Uterus unter besonderer Berücksichtigung der Resistenzanlage von Bakterien unter wiederholter lokal-antibiotischer Behandlung. Zuchthyg., 22, 1987: 173-183.

VLČEK, Z.: Dynamika bakteriálni kontaminace dělohy krav v prủběhu puerperia. Vet. Med. Praha, 14, 1969: 449-454.

VLCEK, Z.: Late puerperium and the new reproductive cycle in cows with regard to restoration of their ovarial activity, estrus and the first postpartal ovulation. Acta vet. Brno, 41, 1982: $75-70$.

VLČEK, Z. - SVOBODOVÁ, R.: Occurrence and antibiotic sensitivity of bacteria present in the cervical mucus of cows in late puerperium and postpuerperal period. Acta vet. Brno 54, 1985: $91-97$. 